\title{
Concentrating molasses distillery wastewater using biomimetic forward osmosis (FO)
} membranes

Singh, N.; Petrinic, I.; Hélix-Nielsen, Claus; Basu, Soumen; Balakrishnan, M.

Published in:

Water Research

Link to article, DOI:

10.1016/j.watres.2017.12.006

Publication date:

2018

Document Version

Peer reviewed version

Link back to DTU Orbit

Citation $(A P A)$ :

Singh, N., Petrinic, I., Hélix-Nielsen, C., Basu, S., \& Balakrishnan, M. (2018). Concentrating molasses distillery wastewater using biomimetic forward osmosis (FO) membranes. Water Research, 130, 271-280.

https://doi.org/10.1016/j.watres.2017.12.006

\section{General rights}

Copyright and moral rights for the publications made accessible in the public portal are retained by the authors and/or other copyright owners and it is a condition of accessing publications that users recognise and abide by the legal requirements associated with these rights.

- Users may download and print one copy of any publication from the public portal for the purpose of private study or research.

- You may not further distribute the material or use it for any profit-making activity or commercial gain

- You may freely distribute the URL identifying the publication in the public portal 


\section{Accepted Manuscript}

Concentrating molasses distillery wastewater using biomimetic forward osmosis (FO) membranes

N. Singh, I. Petrinic, C. Hélix-Nielsen, S. Basu, M. Balakrishnan

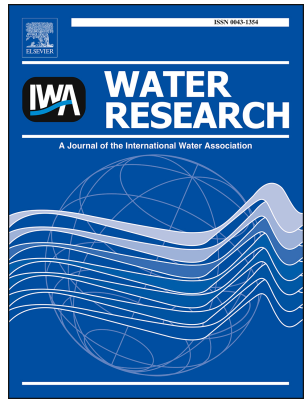

PII: $\quad$ S0043-1354(17)31001-1

DOI: $\quad$ 10.1016/j.watres.2017.12.006

Reference: WR 13404

To appear in: Water Research

Received Date: 21 June 2017

Revised Date: 22 November 2017

Accepted Date: 4 December 2017

Please cite this article as: Singh, N., Petrinic, I., Hélix-Nielsen, C., Basu, S., Balakrishnan, M., Concentrating molasses distillery wastewater using biomimetic forward osmosis (FO) membranes, Water Research (2018), doi: 10.1016/j.watres.2017.12.006.

This is a PDF file of an unedited manuscript that has been accepted for publication. As a service to our customers we are providing this early version of the manuscript. The manuscript will undergo copyediting, typesetting, and review of the resulting proof before it is published in its final form. Please note that during the production process errors may be discovered which could affect the content, and all legal disclaimers that apply to the journal pertain. 


\section{Graphical Abstract}

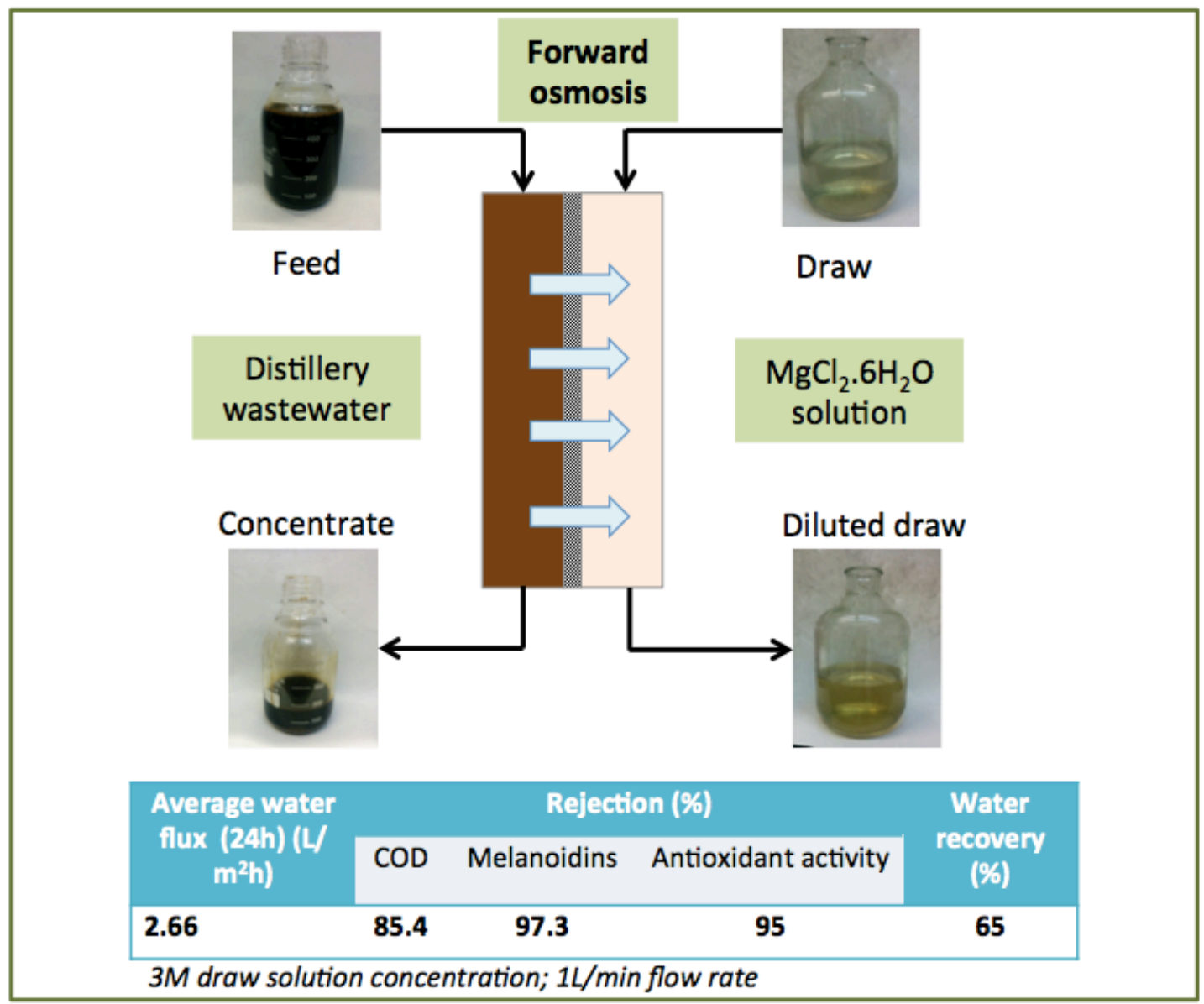


1 Concentrating molasses distillery wastewater using biomimetic forward osmosis

2

\section{(FO) membranes}

${ }^{a}$ Department of Energy and Environment, TERI University, Vasant Kunj, New Delhi 110070, India

${ }^{\mathrm{b}}$ University of Maribor, Faculty for Chemistry and Chemical Engineering, 2000 Maribor, Slovenia

${ }^{\mathrm{c}}$ The Energy and Resources Institute (TERI), Darbari Seth Block, IHC Complex, Lodhi Road, New Delhi-110003, India

${ }^{\mathrm{d}}$ Department of Environmental Engineering, Technical University of Denmark, Bygningstorvet 114, DK2800 Kgs. Lyngby, Denmark

\section{*Corresponding author: S Basu ( $\underline{\text { Subhankar.nifft@gov.in) }}$}

\section{ABSTRACT}

Treatment of sugarcane molasses distillery wastewater is challenging due to the presence of complex phenolic compounds (melanoidins and polyphenols) having antioxidant properties. Due to zero liquid discharge regulations, Indian distilleries continue to explore effective treatment options. This work examines the concentration of distillery wastewater by forward osmosis (FO) using aquaporin biomimetic membranes and magnesium chloride hexahydrate $\left(\mathrm{MgCl}_{2} \cdot 6 \mathrm{H}_{2} \mathrm{O}\right)$ as draw solution. The operational parameters viz. feed solution and draw solution flow rate and draw solution concentration were optimized using $10 \% \mathrm{v} / \mathrm{v}$ melanoidins model feed

\footnotetext{
${ }^{1}$ Current address: National Institute of Foundry and Forge Technology (NIFFT), Ranchi, Jharkhand834003, India
} 
25 solution. This was followed by trials with distillery wastewater. Under the conditions

26 of this work, feed and draw flow rates of $1 \mathrm{~L} / \mathrm{min}$ and draw solution concentration of

$272 \mathrm{M} \mathrm{MgCl}_{2} \cdot 6 \mathrm{H}_{2} \mathrm{O}$ for melanoidins model solution and $3 \mathrm{M} \mathrm{MgCl}_{2} \cdot 6 \mathrm{H}_{2} \mathrm{O}$ for distillery

28 wastewater were optimal for maximum rejection. Rejection of $90 \%$ melanoidins, $96 \%$

29 antioxidant activity and 84\% COD was obtained with melanoidins model feed, with a

30 corresponding water flux of $6.3 \mathrm{~L} / \mathrm{m}^{2} \mathrm{~h}$. With as-received distillery wastewater, the

31 rejection was similar $(85-90 \%)$ to the melanoidins solution, but the water flux was

32 lower $\left(2.8 \mathrm{~L} / \mathrm{m}^{2} \mathrm{~h}\right)$. Water recovery from distillery wastewater over $24 \mathrm{~h}$ study period

33 was higher with FO (70\%) than reported for RO (35-45\%). Repeated use of the FO

34 membrane over five consecutive $24 \mathrm{~h}$ cycles with fresh feed and draw solutions and

35 periodic cleaning showed consistent average water flux and rejection of the feed 36 constituents.

37

38 Keywords: Forward Osmosis (FO); Biomimetic aquaporin membranes; Molasses

39 distillery wastewater; Melanoidins; Antioxidant activity. 


\section{Introduction}

Sugarcane molasses based alcohol distilleries in India are one of the most water intensive and polluting industrial sectors with a fresh water consumption of about 9$21 \mathrm{~L} / \mathrm{L}$ alcohol and wastewater generation of 7-15 L/L alcohol (GoI, 2014). The wastewater has a very high organic load, low $\mathrm{pH}$, high total dissolved solids, unpleasant odor and dark brown color. A major cause of color is melanoidins, a product of Maillard reaction between reducing sugars and amino acids, which constitutes 2\% (w/v) of the wastewater (Arimi et al., 2014; Yadav and Chandra, 2012). Melanoidins are characterized by complex structure, possess antioxidant properties and are not readily biodegradable. The presence of these compounds deters biological treatment and color removal in distillery wastewater poses a major challenge. On the other hand, its antioxidant properties can be exploited in applications like food preservation and personal care products. Considering the stringent regulations imposed by the Central Pollution Control Board (CPCB) on fresh water consumption (maximum of $15 \mathrm{~L} / \mathrm{L}$ of alcohol production) and zero liquid discharge (ZLD) from distilleries, alternatives to existing treatment options like anaerobic digestion, incineration and reverse osmosis continue to be of interest. As fresh water is required for various non-process applications like steam generation, cooling tower make-up water, washing of fermenters, distillation units, floors etc., appropriately treated wastewater offers potential for reuse. Furthermore, antioxidant components in distillery wastewater could be an additional value added resource that could be recovered.

Forward osmosis (FO) is a membrane based separation process operating on osmotic pressure difference between the low osmotic pressure feed solution and the 
65 high osmotic pressure draw solution separated by a semi-permeable membrane. In combination with other membrane separation processes like reverse osmosis, membrane distillation and microfiltration, FO has been used for treatment of various complex wastewaters to either enrich the feed in trace components by reducing the feed volume or to reclaim the wastewater for direct potable reuse. Examples of such applications include (i) selective removal of pharmaceutical micropollutants

71 (carbamazepine, diclofenac, ibuprofen and naproxen) from synthetic feed (Madsen et al., 2015; D’Haese et al., 2013; Jin et al., 2012; Xie et al., 2012; Hancock et al., 2011; Linares et al., 2011); (ii) dewatering drilling wastewater from oil and gas exploration (Hickenbottom et al., 2013); (iii) treatment of domestic wastewater in osmotic membrane reactor (OMBR) (Zhang et al., 2014; Alturki et al., 2012; Zhang et al., 2012a; 2012b; Cornelissen et al., 2010; Achilli et al., 2009); (iv) treatment of municipal wastewater (Hey et al., 2017; Hey et al., 2016a; 2016b); (v) nutrient recovery from domestic wastewater (Devia et al., 2015); (vi) upgrading rain water to replace fresh water for cooling water make-up in steam plant (Wang et al., 2014). In most of the above-listed applications, cellulose triacetate (CTA) and thin film composite (TFC) commercial FO membranes were used. CTA membrane was compared with newly developed biomimetic aquaporin membrane for rejection of three trace organics. Partial rejection was reported with CTA membrane whereas over 97\% rejection was obtained with aquaporin membrane (Madsen et al., 2015). CTA and TFC membranes were also tested along with aquaporin membranes for municipal wastewater treatment (Hey et al., 2016a; 2016b). Biomimetic FO membranes have been largely studied for desalination (Grzelakowski et al., 2015, Tang et al., 2013) where high water flux $\left(\sim 20 \mathrm{~L} / \mathrm{m}^{2} \mathrm{~h}\right)$ and high salt rejection $(\sim 97 \%)$ have been obtained at 5 bar (Zhao et al., 2012). 
This work investigates the applicability of FO for dewatering sugarcane

91 molasses distillery wastewater while concentrating the color imparting constituents.

92 Initial experiments to optimize the FO operational conditions (flow rate of draw

93 solution and feed solution, draw solution concentration and operation time) were done

94 using melanoidins model solution. This was followed by trials with distillery

95 wastewater. Biomimetic aquaporin based FO membranes were used and the FO

96 performance (water flux, reverse salt flux, rejection) over time was evaluated.

97

\section{Materials and method}

99

100

\subsection{Materials}

101

Thin film composite (TFC) FO membranes with aquaporin proteins embedded

103 into the polyamide layer were gifted by Aquaporin A/S, Denmark. These Aquaporin

104 Inside $^{\mathrm{TM}}$ membranes (Table $\mathrm{S} 1$ in supplementary data sheet) were characterized by

105 high water and low reverse salt flux and are stable between pH 2-11 (Perry et al.,

106 2015). Industrial grade magnesium chloride hexahydrate $\left(\mathrm{MgCl}_{2} \cdot 6 \mathrm{H}_{2} \mathrm{O}\right)$ purchased

107 from Advance Chemical Sales Corporation, New Delhi was used for preparing the

108 draw solutions. All the other chemicals were of analytical grade and used as obtained.

109 Deionized water of conductivity $0.005 \mu \mathrm{S} / \mathrm{cm}$ was used for baseline experiments to

110 evaluate water flux and reverse salt flux. Synthetic melanoidins was prepared in the

111 laboratory using equimolar glucose and glycine solutions autoclaved at $120^{\circ} \mathrm{C}$ for 15

112 minutes (Dahiya et al., 2001). The $\mathrm{pH}$ of the solution was adjusted to 7. Synthetic

113 melanoidins $(10 \% \mathrm{v} / \mathrm{v})$ prepared in deionized water was used as model feed solution

114 to optimize the operational parameters. Molasses distillery wastewater was collected 
115 from sugar-distillery complex in Northern India (Simbhaoli Sugars Limited,

116 Brajnathpur unit, Uttar Pradesh). The wastewater was stored at $4^{\circ} \mathrm{C}$ and was used 117 without dilution.

\subsection{Experimental procedure}

Figure 1 shows the schematic representation of the experimental set-up. The

122 FO test cell was locally fabricated with symmetric flow channels and active 123 membrane area of $0.0043 \mathrm{~m}^{2}$. Membranes were soaked in deionized water for about 12430 minutes before placing in the FO cell between two stainless steel meshes. The 125 membrane active side faced the feed solution. Kemflo booster pumps (Electrotech 126 Industries, India) with maximum flow rate of $1.8 \mathrm{~L} / \mathrm{min}$ were used to circulate feed 127 solution and draw solution on either side of the membrane. Flow rate was controlled 128 by adjusting the valve settings and was measured using in-line flow meter on feed 129 side and draw side. The feed solution container was placed on an analytical balance 130 (A\&D, Japan) connected to a computer to record the weight change every 5 minutes. 131 Conductivity of the feed solution for deionized water was measured continuously 132 using conductivity meter (Acmas Technology, India) with a $1 \mathrm{mS} / \mathrm{cm}$ probe. Draw 133 solution stored in a large tank was placed on a magnetic stirrer (IKA, India) and 134 constantly stirred at $500 \mathrm{rpm}$. All the experiments were done in duplicate using fresh 135 membranes.

137 Figure 1. Schematic representation of FO experimental set-up. 
139 The water flux $\left(\mathrm{J}_{\mathrm{w}}\right)$ in $\mathrm{L} / \mathrm{m}^{2} \mathrm{~h}$ and reverse salt flux $\left(\mathrm{J}_{\mathrm{s}}\right)$ in $\mathrm{g} / \mathrm{m}^{2} \mathrm{~h}$ for deionized water

140 feed was calculated by Eq. (1) and (2) respectively,

$141 \quad \mathrm{~J}_{\mathrm{w}}=\frac{\Delta \mathrm{V}}{\mathrm{AX} \Delta \mathrm{t}}$

$$
I_{s}=\frac{\left(V_{t} C_{t}-V_{0} C_{0}\right)}{A \times \Delta t}
$$

where, $\Delta \mathrm{V}$ is the volume change of feed solution, $\mathrm{A}$ is the effective membrane area,

$\Delta \mathrm{t}$ is the measuring time interval $(5 \mathrm{~min}), \mathrm{V}_{0}, \mathrm{~V}_{\mathrm{t}}$ are volume of the feed solution at time $=0$ and time $=\mathrm{t}$ respectively, $\mathrm{C}_{0}, \mathrm{C}_{\mathrm{t}}$ are the salt concentrations of draw solution at time $\mathrm{t}=0$ and time $=\mathrm{t}$ respectively. The salt concentration was determined from the standard curve between total dissolved solids (TDS) (mg/L) and conductivity $(\mu \mathrm{S} / \mathrm{cm})$. The TDS of $\mathrm{MgCl}_{2} \cdot 6 \mathrm{H}_{2} \mathrm{O}$ for preparing the standard curve was determined by gravimetric method and conductivity was measured by conductivity meter. with deionized water feed and $1 \mathrm{M}$ and $3 \mathrm{M} \mathrm{MgCl} 2 \cdot 6 \mathrm{H}_{2} \mathrm{O}$ draw solutions. The effect of operational parameters on water flux and rejection was studied using $10 \%$ melanoidins model feed solution. Depending upon the experiment duration, feed volume varied from $0.25 \mathrm{~L}$ to $1 \mathrm{~L}$ and the corresponding draw solution from $1 \mathrm{~L}$ to 4 L. $0.25 \mathrm{~L}$ melanoidins model feed was taken against $1 \mathrm{~L}$ of $2 \mathrm{M} \mathrm{MgCl}_{2} \cdot 6 \mathrm{H}_{2} \mathrm{O}$ and $3 \mathrm{~h}$ 158 experiments were conducted to optimize draw solution concentration $(1 \mathrm{M}, 2 \mathrm{M}$ and $1593 \mathrm{M}$ at fixed flow rate of $1 \mathrm{~L} / \mathrm{min})$ and flow rate $(0.8 \mathrm{~L} / \mathrm{min}, 1 \mathrm{~L} / \mathrm{min}$ and $1.5 \mathrm{~L} / \mathrm{min}$ at 160 fixed draw solution concentration of $2 \mathrm{M}$ ). The flow rates of feed solution and draw 161 solution were maintained same throughout the experiment to create similar turbulence 162 on both sides of the membrane. Effect of time (4h to $24 \mathrm{~h}$ ) was also studied under 163 optimized flow rate and draw solution concentration. Subsequently, melanoidins 
164 model feed was replaced by distillery wastewater and experiments were carried out at

165 fixed flow rate $(1 \mathrm{~L} / \mathrm{min})$. Since the osmotic pressure of distillery wastewater was

166 higher than that of $10 \%$ melanoidins solution, the draw solution concentration was

167 increased up to $4 \mathrm{M}$.

168 Stability of the FO membranes for distillery wastewater concentration was

169 studied at fixed flow rate and draw solution concentration over five $24 \mathrm{~h}$ cycles (C1-

170 C5). Fresh wastewater and draw solution was used for each cycle. Before each new

171 cycle, feed and draw solution in the module and pipeline was replaced by deionized

172 water to wash out any residual feed solution or draw solution from the previous cycle.

173 For physical cleaning, the membrane was cleaned by circulating $0.5 \mathrm{~L}$ deionized

174 water on both sides of the membrane at $1.8 \mathrm{~L} / \mathrm{min}$ for 30 minutes before the next FO

175 cycle. Chemical cleaning was done by circulating $0.5 \mathrm{~L}$ of $0.5 \mathrm{~N} \mathrm{NaOH}$ solution for 30

176 minutes at $1.8 \mathrm{~L} / \mathrm{min}$ on both sides of the membrane, followed by flushing with

177 deionized water.

178

$179 \quad 2.3$ Analytical methods

180

Feed solution, before and after FO, was analyzed for melanoidins, COD and

182 antioxidant activity. COD was measured using standard method of water and

183 wastewater analysis by APHA. Melanoidins content was determined by absorbance at

$184475 \mathrm{~nm}$ in a UV-Vis spectrophotometer (Aquamate, India) (Dahiya et al., 2001).

185 Trolox equivalent antioxidant capacity (TEAC), determined by the capacity to

186 decolorize $\mathrm{ABTS}^{+}$radical solution in 2 minutes (Rufián-Henares and Morales, 2007),

187 was used as a measure of antioxidant activity. Rejection (r) of melanoidins, COD and 
188 antioxidants was determined using Eq. 3 and water recovery $\left(\mathrm{f}_{\mathrm{c}}\right)$ was calculated by

189 Eq. 4,

$190 \quad r=\frac{x_{t} v_{t}}{X_{0} V_{0}} \times 100 \%$

$191 f_{c}=\frac{\Delta V}{V_{0}} \times 100 \%$

192 where $X_{t}$ and $X_{0}$ are the melanoidins concentration $(g / L)$, COD concentration $(g / L)$,

193 or antioxidant activity $(\mathrm{mM})$ as per analysis, $\mathrm{V}_{0}$ and $\mathrm{V}_{\mathrm{t}}$ are volume of the feed solution

194 at filtration time $\mathrm{t}=0$ and $\mathrm{t}=\mathrm{t}$ respectively.

195 The osmomolarity (Osmol/kg) of the solutions was determined using Gonotec 196 Osmomat 010 freezing point cryoscopic osmometer (Germany) and the value was 197 converted to osmotic pressure using modified Morse equation (Wilson and Stewart, 198 2013). The morphology of the membranes was studied by scanning electron 199 microscopy (SEM) using a Zeiss-EVO/MA10 instrument (Zeiss, Germany). The 200 membrane samples were air dried and freeze fractured under liquid nitrogen. The 201 samples were coated with $\mathrm{Pd}$ in an Ar atmosphere before examination. Membrane 202 zeta potential was measured using $1 \mathrm{mM} \mathrm{KCl}$ solution with polypropylene membrane 203 as reference (SurPASS electrokinetic analyser, Anton-Paar, Graz, Austria).

\section{Results and discussions}

\subsection{Membrane and feed solution characteristics}

The water flux (Figure S1 in supplementary data sheet) of the membrane with

$2091 \mathrm{M}$ draw solution was $6 \mathrm{~L} / \mathrm{m}^{2} \mathrm{~h}$ and the corresponding reverse salt flux relative to the 210 water flux $\left(\mathrm{J}_{\mathrm{s}} / \mathrm{J}_{\mathrm{w}}\right)$ was $0.06 \mathrm{~g} / \mathrm{L}$. At a higher draw solution concentration of $3 \mathrm{M}$, both

211 the water flux and reverse salt flux increased to $8 \mathrm{~L} / \mathrm{m}^{2} \mathrm{~h}$ and $0.6 \mathrm{~g} / \mathrm{L}$ respectively. The 
212 membrane morphology and zeta potential are shown in Figure 2(a) and (b)

213 respectively. The SEM image of active layer shows the presence of embedded

214 aquaporin proteins on a polyamide layer. The protein vesicles appear evenly

215 distributed on the surface. The pitted surface is likely due to the loss of aquaporin

216 protein vesicles during freeze fracturing of the membranes for SEM analysis. The

217 isoelectric point of the virgin membrane lies approximately at $2.9 \mathrm{pH}$. At neutral $\mathrm{pH}$

218 of 7 , the decreasing negative potential becomes constant between $-80 \mathrm{mV}$ and $-90 \mathrm{mV}$.

219 This is consistent with the membrane surface having both acidic and basic functional 220 groups.

Figure 2. Virgin biomimetic membrane: (a) SEM image of the top surface, and (b) zeta potential measurement.

The average characteristics of the two feed solutions used in this study are presented in Table 1. As-is synthetic melanoidins prepared by heating glucose and 227 glycine does not have any free water molecules; it also has high osmotic pressure 228 (around 55 bar). Thus, the melanoidins preparation was diluted to $10 \%$ so that the 229 absorbance at $475 \mathrm{~nm}$ of model feed solution was similar to that of real distillery 230 wastewater. The $\mathrm{pH}$ of the model feed solution $(\mathrm{pH} 7.3)$ and distillery wastewater $(\mathrm{pH}$ 2314.3 ) was different but $\mathrm{pH}$ adjustment of distillery wastewater leads to precipitation of 232 melanoidins molecules. The antioxidant activity, conductivity and COD were higher 233 for distillery wastewater as in addition to melanoidins, it contains other constituents 234 like polyphenols and salts. 
3.2 Concentration of melanoidins model feed solution

240 Figure 3 shows the effect of varying flow rate and draw solution concentration on 241 water flux, rejection of COD, melanoidins and antioxidant activity. The flux profiles 242 with time are presented as supplementary data (Figure S2a and Figure S2b). At a fixed draw solution concentration of $2 \mathrm{M}$, the average water flux for all

244 the three flow rates remained in the range of $6-7 \mathrm{~L} / \mathrm{m}^{2} \mathrm{~h}$ (Figure 3a). The rejection 245 obtained was $61-85 \%$ (COD), $80-90 \%$ (melanoidins) and 78-98\% (antioxidant 246 activity). COD rejection decreases visibly at higher flow rate. As per the analytical 247 methods used, COD measured the concentration of all organics, melanoidins 248 measured the colored compounds and the antioxidant activity measured the 249 compounds with radical scavenging capacity. Melanoidins consist of a range of small 250 to large polymeric molecules (Wang et al., 2011; Le et al., 1998; Yaylayan and 251 Kaminsky, 1998). The synthetic melanoidins prepared in this work are therefore 252 composed of polymers with broad range of molecular weight between 5-40 kDa 253 (Cämmerer et al., 2002) along with some unreacted sugars and amino acids. Further, 254 melanoidins contain a pure melanoidins core (typically large in size) with bound 255 melanoidins polymers of smaller size; the latter have higher color and higher 256 antioxidant activity than the counterpart pure melanoidins core (Rufian-Henares and 257 Morales, 2007).

258 The increase in flow rate from $0.8 \mathrm{~L} / \mathrm{min}$ to $1.5 \mathrm{~L} / \mathrm{min}$ of feed solution and 259 draw solution creates turbulence on the membrane active side and support side 260 respectively. This turbulence decreases the concentrative internal concentration 261 polarization on the feed solution side, while the increase in the flow rate on the draw 
262 solution side aggravates the dilutive external concentration polarization; this

263 eventually increases the mass transfer (Hawari et al., 2016). As the synthetic

264 melanoidins feed solution contains low molecular weight compounds (unreacted

265 sugars, amino acids, small colored compounds etc.) that contributes to the COD,

266 movement of these small molecules to the draw solution side across the membrane on

267 increasing the flow rate to $1.5 \mathrm{~L} / \mathrm{min}$ lowers the COD rejection. The higher molecular

268 weight melanoidins (including the bound melanoidins polymers) are largely retained

269 by the membrane thus showing high rejection of antioxidant activity and melanoidins

270 content. The fact that some small colored compounds pass through the membrane is

271 confirmed by increase in the absorbance of the post-FO draw solution. Of the three

272 flow rates, $1 \mathrm{~L} / \mathrm{min}$ was the best in terms of higher rejection; the water flux was also

273 most stable throughout the $3 \mathrm{~h}$ study period.

274

275 Figure 3. Water flux, rejection of COD, melanoidins and antioxidant activity at (a)

276 varying flow rate (2M draw solution, $3 \mathrm{~h}$ operation time), and (b) varying draw

277 solution concentration (1 L/min flow rate, 3 h operation time).

At a fixed flow rate of $1 \mathrm{~L} / \mathrm{min}$, draw solution concentration was varied 280 between $1 \mathrm{M}$ and $3 \mathrm{M}$ (Figure $3 \mathrm{~b}$ ). Increasing the draw solution concentration enhances 281 the water flux as higher solute concentration corresponds to higher osmotic pressure, 282 raising the osmotic gradient across the membrane. The maximum average water flux 283 was $7.6 \mathrm{~L} / \mathrm{m}^{2} \mathrm{~h}$ with $3 \mathrm{M}$ draw solution. At $2 \mathrm{M}$ and $3 \mathrm{M}$ draw solution concentration, 284 rejection of melanoidins (86-90\%) and antioxidant activity (96-98\%) was similar but 285 COD rejection decreased from $84 \%$ (2M) to $57 \%(3 \mathrm{M})$. This may be attributed to 286 increased concentration polarization across the membrane at higher water flux (7.6 
$287 \mathrm{~L} / \mathrm{m}^{2} \mathrm{~h}$ at $3 \mathrm{M}$ compared to $6.3 \mathrm{~L} / \mathrm{m}^{2} \mathrm{~h}$ at $2 \mathrm{M}$ ), confirming that there is a limit to

288 increasing draw solution concentration to improve FO performance (Klaysom et al.,

289 2013). Increase in the concentration gradient across the membrane at higher draw

290 solution concentration of $2 \mathrm{M}$ and $3 \mathrm{M}$ has no influence on the antioxidant activity and

291 melanoidins rejection. This indicates that the radical scavenging components in the

292 feed solution (melanoidins core with bound compounds) get concentrated and the FO

293 membrane restricts the passage of high molecular weight melanoidins compounds.

294 The decrease in COD rejection is once again attributed to the migration of the 295 unreacted low molecular weight sugars, amino acids etc. present in the feed solution.

296 Based on these results, flow rate of $1 \mathrm{~L} / \mathrm{min}$ and draw solution concentration

297 of $2 \mathrm{M}$ was chosen. Figure $4 \mathrm{a}$ shows the FO performance over a $24 \mathrm{~h}$ period. The water

298 flux declined marginally from $5.92 \mathrm{~L} / \mathrm{m}^{2} \mathrm{~h}(4 \mathrm{~h})$ to $5.15 \mathrm{~L} / \mathrm{m}^{2} \mathrm{~h}(24 \mathrm{~h})$. The water flux

299 variation with time is presented in Figure S3 of the supplementary data. Rejection of

300 COD, melanoidins and antioxidant activity increased initially but a drop was observed

301 at $16 \mathrm{~h}$ before the values for all the parameters stabilized between $85-98 \%$ at $24 \mathrm{~h}$. It

302 was anticipated that increasing duration of FO would steadily increase the rejection.

303 The observed fall at $16 \mathrm{~h}$ could be due to deposition of melanoidins on the active side

304 of the membrane surface, which would have reduced its content in the feed solution

305 that was analyzed for calculating the rejection. The deposits were subsequently re-

306 suspended in the feed due to the scouring action of the feed flow so an increase in

307 rejection is seen after $24 \mathrm{~h}$ of operation. The membrane surface after $24 \mathrm{~h}$ FO shows a

308 thin, non-uniform layer of melanoidins deposition. This deposition was only on the

309 surface and the material was readily re-suspended when the used membrane was

310 stored in water. The SEM image of the used membrane top surface at a high

311 magnification of 10000X (Figure 4c) shows no visible foulants. 
313 Figure 4. (a) Water flux as a function of time and average rejection of COD,

314 melanoidins and antioxidant activity over $24 \mathrm{~h}$, and (b) photo of membrane active side

315 after $24 \mathrm{~h}$ operation (c) SEM image of the top surface of used membrane (24h 316 operation).

\subsection{Concentration of distillery wastewater}

As osmotic pressure of distillery wastewater (40 bar) is substantially higher

than $10 \%$ melanoidins (5 bar), higher draw solution concentration would be required for effective dewatering. Figure 5a shows the water flux and rejection results at varying draw solution concentrations for $4 \mathrm{~h}$ duration. Since distillery wastewater has low $\mathrm{pH}$ (4.7) it was adjusted to $\mathrm{pH} 7$ to replicate the melanoidins model feed. There were fluctuations in the water flux over time and the average value was marginally of supplementary data sheet). Due to $\mathrm{pH}$ adjustment, feed COD dropped to $73 \mathrm{~g} / \mathrm{L}$, from $120 \mathrm{~g} / \mathrm{L}$ for as-received wastewater. The reason for this change could be and intensity of color (absorbance measured at $475 \mathrm{~nm}$ ) were observed. Further

331 experiments were therefore continued with as-received wastewater without $\mathrm{pH}$ 332 adjustment. Increasing the draw solution concentration from $2 \mathrm{M}$ to $4 \mathrm{M}$ enhanced the 333 water flux while the rejection of COD (82-90\%), melanoidins (87-92\%) and 334 antioxidant activity (84-92\%) remained similar. 
2. The initial water flux for draw solution concentrations of $3 \mathrm{M}$ and $4 \mathrm{M}$ was around 4

$338 \mathrm{~L} / \mathrm{m}^{2} \mathrm{~h}$, but it reduced to $2.66 \mathrm{~L} / \mathrm{m}^{2} \mathrm{~h}(3 \mathrm{M})$ and $2.54 \mathrm{~L} / \mathrm{m}^{2} \mathrm{~h}(4 \mathrm{M})$ over $24 \mathrm{~h}$ study period.

339 The water recovery after $24 \mathrm{~h}$ was marginally higher at $3 \mathrm{M}(65 \%)$ than at $4 \mathrm{M}(58 \%)$.

340 The experiment with $3 \mathrm{M}$ draw solution gave better water flux and recovery compared

341 to the experiment at $4 \mathrm{M}$. This could be due to the higher fouling with the $4 \mathrm{M}$ draw

342 solution compared to the $3 \mathrm{M}$ draw solution, because the $4 \mathrm{M}$ draw solution gave

343 higher flux in the beginning (at least $4 \mathrm{~h}$, as proved in Fig 5a) and then decreased with

344 time. The critical water flux (Zou et al., 2013) for distillery wastewater as feed is well

345 below $4 \mathrm{~L} / \mathrm{m}^{2} \mathrm{~h}$ (Figure S5 in supplementary sheet) and the "critical draw solution

346 concentration" (the threshold draw solution concentration above which severe fouling

347 occurs) is also below $3 \mathrm{M}$. The long-term study indicates the fouling susceptibility of 348 the membrane.

349 Table 2 shows that the melanoidins and antioxidant activity rejection remained 350 constant but COD rejection at $3 \mathrm{M}$ reduced marginally from $90 \%$ (4h) to $85.2 \%$ (24h).

351 The slight decrease in COD rejection was due to migration of small color causing 352 compounds across the membrane with increasing concentration polarization. This was 353 supported by the observation that the draw solution became lightly colored, with 354 increase in absorbance at $475 \mathrm{~nm}$, at the end of the $24 \mathrm{~h}$ run.

355 A mass balance was done for the $24 \mathrm{~h}$ FO with distillery wastewater using $3 \mathrm{M}$ 356 draw solution. The mass balance shows that from the initial COD $(64.2 \mathrm{~g})$, 357 melanoidins (40.2 g) and antioxidant activity (36.5 g) present in the feed, the 358 concentrate retained $54.7 \mathrm{~g} \mathrm{COD}, 39.09 \mathrm{~g}$ melanoidins and $34.4 \mathrm{~g}$ antioxidant activity. 359 The balance was in the permeate or deposited on the membrane. The calculated mass 360 of melanoidins in the permeate was $1.075 \mathrm{~g}$ while the experimentally determined 361 value was $0.5 \mathrm{~g}$ indicating around $0.575 \mathrm{~g}$ is deposited on the membrane (Figure $5 \mathrm{c}$ ). 
363 Figure 5. Distillery wastewater dewatering (a) over 4 h by varying draw solution 364 concentration $(2 \mathrm{M}-4 \mathrm{M})$ : water flux and rejection of COD, melanoidins and 365 antioxidant activity (b) over $24 \mathrm{~h}$ at $3 \mathrm{M}$ and $4 \mathrm{M}$ draw solution concentration: water 366 flux and water recovery, and (c) mass balance of melanoidins over $24 \mathrm{~h}$ FO with $3 \mathrm{M}$ 367 draw solution.

Table 2. Characteristics of distillery wastewater concentrate after $24 \mathrm{~h}$ operation.

The FO performance with the synthetic melanoidins (Figure 3b) and real distillery wastewater (Figure 5a) with increasing draw solution concentration is different. As summarized in Table 1, there is considerable difference in the properties of the two feed solutions both in terms of physical properties (viscosity and osmotic pressure) as well as composition (e.g. the COD of the real wastewater is nearly 6 times higher than that of the synthetic melanoidins feed solution). Due to the high COD in the real wastewater, the external concentration polarization and fouling is higher and could be a cause for improved rejection. Membrane fouling is observed and regular physical/chemical cleaning is required to restore the water flux (as shown below in Figure 6a).

Stability of the FO membrane for concentration of as-received distillery wastewater was studied using $3 \mathrm{M}$ draw solution and flow rate of $1 \mathrm{~L} / \mathrm{min}$ over five 383 consecutive $24 \mathrm{~h}$ cycles (C1-C5). As shown in Figure 6a, there was a steady drop in 384 the water flux from $4 \mathrm{~L} / \mathrm{m}^{2} \mathrm{~h}$ to $2 \mathrm{~L} / \mathrm{m}^{2} \mathrm{~h}$ after $12 \mathrm{~h}$ filtration and further decrease to 1 $385 \mathrm{~L} / \mathrm{m}^{2} \mathrm{~h}$ after $24 \mathrm{~h}$. This decreasing trend was found to be similar in all the five cycles. 386 Physical cleaning (after C1, C2 and C4) and chemical cleaning (after C3) restored the 
387 water flux to approximately its initial value $\left(4 \mathrm{~L} / \mathrm{m}^{2} \mathrm{~h}\right) . \mathrm{C} 1$ (fresh membrane) and $\mathrm{C} 4$

388 (chemically cleaned membrane) showed higher water recovery of $70 \%$ while C2, C3, 389 and C5 (physically cleaned membrane) showed water recovery of 52\%. Fouling in 390 osmotically driven membrane process is usually external and reversible (She et al., 391 2016); the reversibility is also due to the fouling layer being loose and sparse (Lee et 392 al., 2010). The external fouling can be easily removed by physical cleaning. However, 393 in distillery wastewater, the functional groups in melanoidins ( $\mathrm{R}-\mathrm{OH}$ and $\mathrm{R}-\mathrm{COOH})$ 394 are likely to interact with the membrane surface, causing irreversible fouling. Thus 395 intermittent chemical cleaning of the membrane improves the membrane reusability. Figure $6 \mathrm{~b}$ shows that the average water flux over the 5 cycles is similar $397\left(2.5 \pm 0.3 \mathrm{~L} / \mathrm{m}^{2} \mathrm{~h}\right)$. This indicates that periodic membrane cleaning removes the solids 398 deposited on the membrane surface and improves the longevity of the membrane. The 399 rejection of melanoidins $(90 \pm 4 \%)$, antioxidant activity $(95 \pm 3 \%)$, and COD $(85 \pm 5 \%)$ 400 was high and did not show much variation among the five cycles. 
402 Figure 6. Biomimetic FO membrane performance for distillery wastewater rejection 403 over 5 cycles (C1-C5), each of 24 h duration with physical/chemical cleaning (a) water

404 flux and water recovery, and (b) average water flux and corresponding rejection of 405 COD, melanoidins and antioxidant activity.

\subsection{Suitability of FO for distillery wastewater treatment}

To comply with ZLD norms, Indian distilleries are adopting several measures.

410 Due to the high organic load, anaerobic treatment (biomethanation) with biogas

411 generation is the most common primary treatment. In some distilleries, the 412 biomethanated wastewater is further concentrated by reverse osmosis (RO) or 413 evaporation. Both the biomethanated wastewater and the concentrate (from RO or 414 evaporation) are being used for biocomposting with sugarcane press mud, a sugar 415 industry waste. In a typical operation, the ratio of wastewater to press mud is 416 maintained at 2.5:1 or 3.5:1 (GoI, 2014). Yet another treatment is evaporation 417 followed by incineration of the concentrate. Options like RO, evaporation and 418 incineration are characterized by high capital cost and are highly energy intensive.

419 Biocomposting requires land, is limited by availability of sugarcane press-mud, and is 420 difficult to carry out in the rainy season; further, the compost requires time to 421 stabilize.

422 In comparison to wastewater concentration by RO or evaporation, FO could 423 be a relatively energy efficient option. The major advantage with FO is high water 424 recovery and relatively low energy requirement. Water recovery from distillery 425 wastewater over $24 \mathrm{~h}$ study period was higher with FO (70\%) than reported for RO 426 (35-45\%) (Nataraj et al., 2006). In another study, nanofiltration (NF) at 5 bar 
427 transmembrane pressure could only produce a water permeability of $2.66 \mathrm{~L} / \mathrm{m}^{2} \mathrm{~h}$ bar

428 with serious reversible and irreversible fouling (Liu et al., 2013). Organic fouling in

429 FO is mostly reversible and amenable to physical cleaning; it can be easily controlled

430 by optimizing the feed flow rate (Lee et al., 2010). Fouling can be further minimized

431 by selecting a proper draw solution with less back diffusion.

432 The limitation with FO is appropriate management of the diluted draw

433 solution. In some cases, the diluted draw can be utilized e.g. where fertilizers like urea

434 are used as the draw solution, the diluted draw can be directly applied on land.

435 Elsewhere, the diluted draw solution needs to be concentrated by RO for reuse in the

436 FO process. Considering the high osmotic pressure of distillery wastewater (40 bar),

437 the choice of inorganic salts, that are conventional draw solutes, is also somewhat

438 limited. Another challenge in draw solution reuse is its contamination by the feed.

439 The rejection of melanoidins/color components in distillery wastewater by the FO

440 membrane in this work was not $100 \%$, as observed by the change in color of the draw

441 solution. Repeated concentration of the contaminated $\mathrm{MgCl}_{2} \cdot 6 \mathrm{H}_{2} \mathrm{O}$ draw solution by

442 RO will progressively build-up the concentration of the color compounds thereby

443 affecting the properties of the draw solution. Periodic purging of the concentrated

444 contaminated draw solution along with make-up with fresh concentrated draw

445 solution would be necessary to maintain the effectiveness of the draw solution.

446 Further investigations are required to confirm if the combined FO-RO process for

447 distillery wastewater treatment could be a better option than $\mathrm{RO}$ alone in terms of

448 acceptable OPEX (operational expenditure) and CAPEX (capital expenditure).

\section{Conclusions}


452

453

454

455

456

457

474 Achilli, A., Cath, T.Y., Marchand, E.A and Childress, A.E., The forward osmosis 475 membrane bioreactor: a low fouling alternative to MBR processes, Desalination 238 476

- Melanoidins, the key color and antioxidant component in distillery wastewater, can be concentrated by FO. As rejection is not $100 \%$, the small molecules migrating to the draw side can pose a challenge in draw solution reuse.

- Rejection of COD, melanoidins and antioxidant activity remains high over longterm FO of distillery wastewater. However, both reversible and irreversible membrane fouling occurs.

- Higher water recovery can be obtained from FO of distillery wastewater as compared to RO. Further investigations on membrane fouling and draw solution recovery are required to establish the superiority of FO over RO for the concentration of this wastewater.

\section{Acknowledgements}

The authors gratefully acknowledge support from Department of Science and Technology (DST) and Slovenian Research Agency (ARRS) under the collaborative project grants INT/Slovenia/ P-15/2014 and BI-IN/15-17-001 respectively. CHN also acknowledges support from the Innovation Fund Denmark via the IBISS and MEMENTO projects. NS acknowledges scholarship support from DST under Women Scientists Scheme (WOS-A; grant no. SR/WOS-A/ET-56/2016).

\section{References}

$$
\text { (2009), 10-21. }
$$


478 Alturki, A.A., McDonald, J.A., Khan, S.J., Price, W.E. Nghiem, L.D and Elimelech,

479 M., Removal of trace organic contaminants by the forward osmosis process, Sep. 480 Purif. Technol. 103 (2013), 258-266.

481

482 Arimi, M.M., Zhang, Y., Götz, G., Kiriamiti, K and Geißen, S.U., Antimicrobial 483 colorants in molasses distillery wastewater and their removal technologies, Int. 484 Biodeter. Biodegr. 87 (2014), 34-43.

Cämmerer, B., Jalyschkov, V., and Kroh, L. W., Carbohydrate structures as part of the melanoidin skeleton. Int. Congr. Ser, 1245 (2002), 269-273.

Wessels, L.P., Membrane fouling and process performance of forward osmosis 491 membranes on activated sludge, J. Membr. Sci. 319 (2010), 158-168. membrane fouling and modeling of solute build-up, Water Res. 47 (2013), 52325244.

498 Dahiya, J., Singh, D and Nigam, P., Decolorization of molasses wastewater by cells 499 of Pseudomonas fluorescence immobilized on porous cellulose carrier, Bioresource 500 Technol. 37 (2001), 857-862. 
502 Devia, Y.P., Imai, T., Higuchi, T., Kanno, A., Yamamoto, K., Sekine, M and Le,

503 T.V., Potential of magnesium chloride for nutrient rejection in forward osmosis, J

504 Water Resource Prot. 7 (2015), 730-740.

505

506 GoI, Report by Principal Scientific Advisor to Government of India, (2014)

507 Electronic source: http://psa.gov.in/publications-reports/opportunities-green-

508 chemistry-initiatives-molasses-based-distilleries-2014 (accessed on $3^{\text {rd }}$ January 2016).

509

510 Grzelakowski, M., Cherenet, M.F., Shen, Y and Kumar, M., A framework for

511 accurate evaluation of the promise of aquaporin based biomimetic membranes, J.

512 Membr. Sci. 479 (2015), 223-231.

513

514 Hancock, N.T., Xu, P., Heil, D.M., Bellona, C and Cath, T.Y., Comprehensive bench

515 and pilot-scale investigation of trace organic compounds rejection by forward

516 osmosis, Environ. Sci. Technol. 45 (2011), 8483-8490.

517

518 Hawari, A.H., Kamal, N and Altaee, A., Combined influence of temperature and flow

519 rate of feeds on the performance of forward osmosis, Desalination 398 (2016), 98520105.

522 Hey, T., Bajraktari, N., Davidsson, Å., Vogel, J., Madsen, H. T., Hélix-Nielsen, C., la 523 Cour Jansen, J and Jönsson, K., Evaluation of direct membrane filtration and direct 524 forward osmosis as concepts for compact and energy-positive municipal wastewater 525 treatment, Environ. Technol. (2017) 1-13. 
527 Hey, T., Bajraktari, N., Vogel, J., Hélix-Nielsen, C., la Cour Jansen, J and Jönsson,

528 K., The effects of physicochemical wastewater treatment operations on forward 529 osmosis, Environ. Technol. (2016a) 1-10.

531 Hey, T., Zarebska, A., Bajraktari, N., Vogel, J., Hélix-Nielsen, C., la Cour Jansen, J

532 and Jönsson, K., Influences of mechanical pretreatment on the non-biological 533 treatment of municipal wastewater by forward osmosis, Environ. Technol. (2016b) 153410.

536 Hickenbottom, K.L., Hancock, N.T., Hutchings, N.R., Appleton, E.W., Beaudry, 537 E.G., $\mathrm{Xu}, \mathrm{P}$ and Cath, T.Y., Forward osmosis treatment of drilling mud and fracturing 538 wastewater from oil and gas operations, Desalination 312 (2013), 60-66.

541 forward osmosis membranes, J. Hazard. Mater. 228 (2012), 55-61.

543 Klaysom, C., Cath, T.Y., Depuydt, T and Vankelecom, I.F.J., Forward and pressure 544 retarded osmosis: potential solutions for global challenges in energy and water 545 supply, Chem. Soc. Rev. 42 (2013) 6959-6989.

547 Le, L.R., Bailey, R.G and Ames, J.M., Separation of Maillard reaction products from 548 xylose-glycine and glucose-glycine model systems by capillary electrophoresis and 549 comparison to reverse phase HPLC, Food Chem. 62 (1998), 425-430.

551 Lee, S., Boo, C., Elimelach, M and Hong, S., Comparison of fouling behavior in 
552 forward osmosis (FO) and reverse osmosis (RO), J. Membr. Sci. 365 (2010), 34-39.

553

554 Linares, R.V., Yangali-Quintanilla, V., Li, Z and Amy, G., Rejection of

555 micropollutants by clean and fouled forward osmosis membrane, Water Res. 45

556 (2011), 6737-6744.

557

558 Liu, M., Zhu, H., Dong, B., Zheng, Y., Yu, S and Gao, C., Submerged nanofiltration 559 of biologically treated molasses fermentation wastewater for the removal of 560 melanoidins, Chem. Eng. J. 223 (2013), 388-394.

561

562 Madsen, H.T., Bajraktari, N., Hélix-Nielsen, C., Van der Bruggen, B and Søgaard, 563 E.G., Use of biomimetic forward osmosis membrane for trace organics removal, J. 564 Membr. Sci. 476 (2015), 469-474.

565

566 Nataraj, S.K., Hosamani, K.M and Aminabhavi, T.M., Distillery wastewater treatment

567 by the membrane - based nanofiltration and reverse osmosis processes, Water Res. 40 568 (2006), 2349-2356.

569

570 Perry, M., Madsen, S.U., Jørgensen, T., Braekevelt, S., Lauritzen, K and Hélix-

571 Nielsen, C., Challenges in commercializing biomimetic membranes, Membranes 5 572 (2015), 685-701.

573

574 Rufián-Henares, J. A and Morales, F. J., Functional properties of melanoidins: in vitro 575 antioxidant, antimicrobial, and antihypertensive activities, Food Res. Int. 40 (2007), 576 995-1002. 
578 She, Q., Wang, R., Fane, A.G and Tang, C.Y., Membrane fouling in osmotically

579 driven membrane processes: A review, J. Membr. Sci. 499 (2016), 201-233.

580

581 Tang, C.Y., Zhao, Y., Wang, R., Hélix-Nielsen, C and Fane, A.G., Desalination by

582 biomimetic aquaporin membranes: Review of status and prospects, Desalination 308

583 (2013), 34-40.

584

585 Wang, H.Y., Qian, H and Yao, W.R., Melanoidins produced by the Maillard reaction:

586 structure and biological activity, Food Chem. 128 (2011), 573-584.

587

588 Wang, W., Zhang, Y., Esparra-Alvarado, M., Wang, X., Yang, H and Xie, Y., Effects

589 of $\mathrm{pH}$ and temperature on forward osmosis membrane flux using rainwater as the 590 makeup for cooling water dilution, Desalination 351 (2014), 70-76.

591

592 Wilson, A.D and Stewart, F.F., Deriving osmotic pressures of draw solutes used in

593 osmotically driven membrane processes, J. Membr. Sci. 431 (2013), 205-211.

594

595 Xie, M., Price, W.E and Nghiem, L.D., Rejection of pharmaceutically active

596 compounds by forward osmosis: role of solution $\mathrm{pH}$ and membrane orientation, Sep.

597 Purif. Technol. 93 (2012), 107-114.

598

599 Yadav, S. and Chandra, R., Biodegradation of organic compounds of molasses 600 melanoidins (MM) from biomethanated distillery spent wash (BMDS) during the 601 decolourisation by a potential bacterial consortium, Biodegradation 23(4) (2012), 1- 
603

604 Yaylayan, V.A and Kaminsky, E., Isolation and structural analysis of Maillard 605 polymers: caramel and melanoidins formation in glycine/glucose model system, Food 606 Chem. 63 (1998), 25-31.

607

608

Zhang, H., Ma, Y., Jiang, T., Zhang, G and Yang, F., Influence of activated sludge 609 properties on flux behavior in osmosis membrane bioreactor (OMBR), J. Membr. Sci. $610 \quad 390-391$ (2012a), 270-276.

612 Zhang, J., Loong, W.L.C., Chou, S., Tang, C., Wang, R and Fane, A.G., Membrane 613 biofouling and scaling in forward osmosis membrane bioreactor, J. Membr. Sci. 403$614404(2012 b), 8-14$.

616 Zhang, X., Ning, Z., Wang, D.K and Costa, J.C.D., Processing municipal wastewaters 617 by forward osmosis using CTA membrane, J. Membr. Sci. 468 (2014), 269-275.

Zhao, Y., Qiu, C., Li, X., Vararattanavech, A., Shen, W., Torres, J., Hélix-Nielsen, C.,

620 Wang, R., Hu, X., Fane, A.G and Tang, C.Y., Synthesis of robust and high621 performance aquaporin-based biomimetic membranes by interfacial polymerization622 membrane preparation and RO performance characterization, J. Membr. Sci. 423-424 623 (2012), 422-428.

624

625 Zou, S., Wang, Y.N., Wicaksana, F., Aung, T., Wong, P.C.Y., Fane, A.G and Tang, 626 C.Y., Direct microscopic observation of forward osmosis membrane fouling by 
627 microalgae: Critical flux and the role of operational conditions, J. Membr. Sci. 436 628 (2013), 174-185.

629 
List of Figures

631

632 Figure 1. Schematic representation of FO experimental set-up.

633

634 Figure 2. Virgin biomimetic membrane: (a) SEM image of the top surface, and (b)

635 zeta potential measurement.

636

637 Figure 3.Water flux, rejection of COD, melanoidins and antioxidant activity at (a)

638 varying flow rate (2M draw solution, $3 \mathrm{~h}$ operation time), and (b) varying draw 639 solution concentration (1 L/min flow rate, 3 h operation time).

640

641 Figure 4. (a)Water flux as a function of time and average rejection of COD, 642 melanoidins and antioxidant activity over $24 \mathrm{~h}$, (b) photo of membrane active side 643 after $24 \mathrm{~h}$ operation, and (c) SEM image of the top surface of used membrane (24h 644 operation).

645

646 Figure 5. Distillery wastewater dewatering (a) over $4 \mathrm{~h}$ by varying draw solution 647 concentration (2M-4M): water flux and rejection of COD, melanoidins and 648 antioxidant activity, and (b) over $24 \mathrm{~h}$ at $3 \mathrm{M}$ and $4 \mathrm{M}$ draw solution concentration: 649 water flux and water recovery, and (c) mass balance of melanoidins over 24h FO with $6503 \mathrm{M}$ draw solution.

651

652 Figure 6. Biomimetic FO membrane performance for distillery wastewater recovery 653 over 5 cycles (C1-C5), each of $24 \mathrm{~h}$ duration with physical/chemical cleaning (a) water 
654 flux and water recovery, and (b) average water flux and corresponding rejection of 655 COD, melanoidins and antioxidant activity.

656

657 


\section{$658 \quad$ List of Tables}

659

660 Table 1. Characteristics of FO feed solutions.

661

662 Table 2. Characteristics of distillery wastewater concentrate after 24 h operation.

663

664 
665 Supplementary Data Sheet

666

667 Figure S1: Water flux profile with deionized water as feed solution and $\mathrm{MgCl}_{2} \cdot 6 \mathrm{H}_{2} \mathrm{O}$

$668(1 \mathrm{M}$ and $3 \mathrm{M})$ as draw solution.

669

670 Figure S2a: Water flux profile at different flow rates $(0.8 \mathrm{~L} / \mathrm{min}, 1 \mathrm{~L} / \mathrm{min}$ and 1.5

$671 \mathrm{~L} / \mathrm{min}$ ) with $2 \mathrm{M}$ draw solution of $\mathrm{MgCl}_{2} \cdot 6 \mathrm{H}_{2} \mathrm{O}$ and $10 \%(\mathrm{v} / \mathrm{v})$ melanoidins feed 672 solution.

673

674 Figure S2b: Water flux profile with different concentrations (1M, 2M, 3M) of $675 \mathrm{MgCl}_{2} \cdot 6 \mathrm{H}_{2} \mathrm{O}$ as draw solution and $10 \%(\mathrm{v} / \mathrm{v})$ melanoidins feed solution, at flow rate 676 of $1 \mathrm{~L} / \mathrm{min}$.

677

678 Figure S3: Water flux profile with $10 \%$ (v/v) melanoidins feed solution and 2M $679 \mathrm{MgCl}_{2} \cdot 6 \mathrm{H}_{2} \mathrm{O}$ draw solution.

680

681 Figure S4: Water flux profile of distillery wastewater feed with different 682 concentration $(2 \mathrm{M}, 3 \mathrm{M}, 4 \mathrm{M})$ of $\mathrm{MgCl}_{2} \cdot 6 \mathrm{H}_{2} \mathrm{O}$ draw solution.

683

684 Figure S5: Comparison of water flux for distillery wastewater and DI water feed 685 solutions using $3 \mathrm{M} \mathrm{MgCl}_{2} \cdot 6 \mathrm{H}_{2} \mathrm{O}$ as draw solution.

686

687 Table S1: Biomimetic membrane specifications (as reported by the manufacturer). 
Table 1. Characteristics of FO feed solutions*

\section{Parameters}

\begin{tabular}{lll}
\hline $\mathrm{pH}$ & $7.3 \pm 0.1$ & $4.3 \pm 0.2$ \\
Conductivity (mS/cm) & $7.47 \pm 0.54$ & $38.87 \pm 1.01$ \\
Chemical Oxygen Demand (COD) (g/L) & $21.78 \pm 2.09$ & $120.78 \pm 17.80$ \\
Trolox equivalent antioxidant capacity & $16.85 \pm 3.31$ & $54.74 \pm 2.26$ \\
(TEAC) (mM) & & $80 \pm 4.26$ \\
Melanoidins (g/L) & $69.75 \pm 4.27$ & $9.46 \pm 0.79$ \\
Polyphenols (g/L) & - & 40 \\
Osmotic pressure (bar) & 5 & $2.07 \pm 0.03$ \\
Viscosity (cP) & $1.56 \pm 0.07$ & \\
\end{tabular}

$10 \%$ melanoidins Distillery wastewater

\section{.}




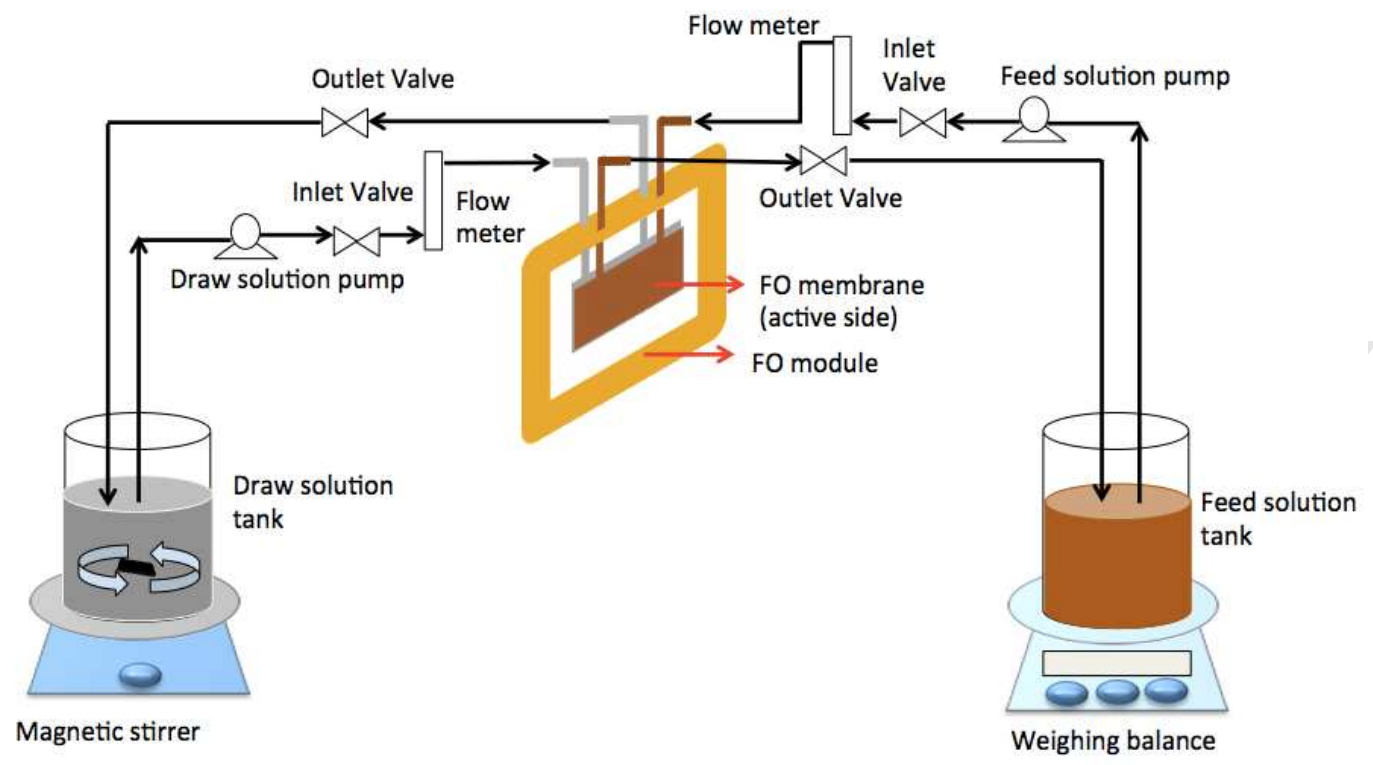

Figure 1.Schematic representation of FO experimental set-up. 
(a)

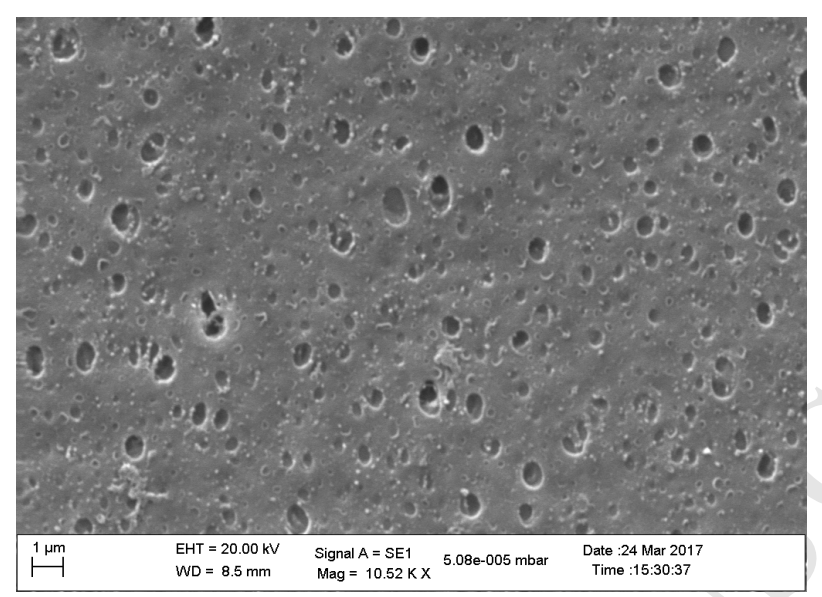

(b)

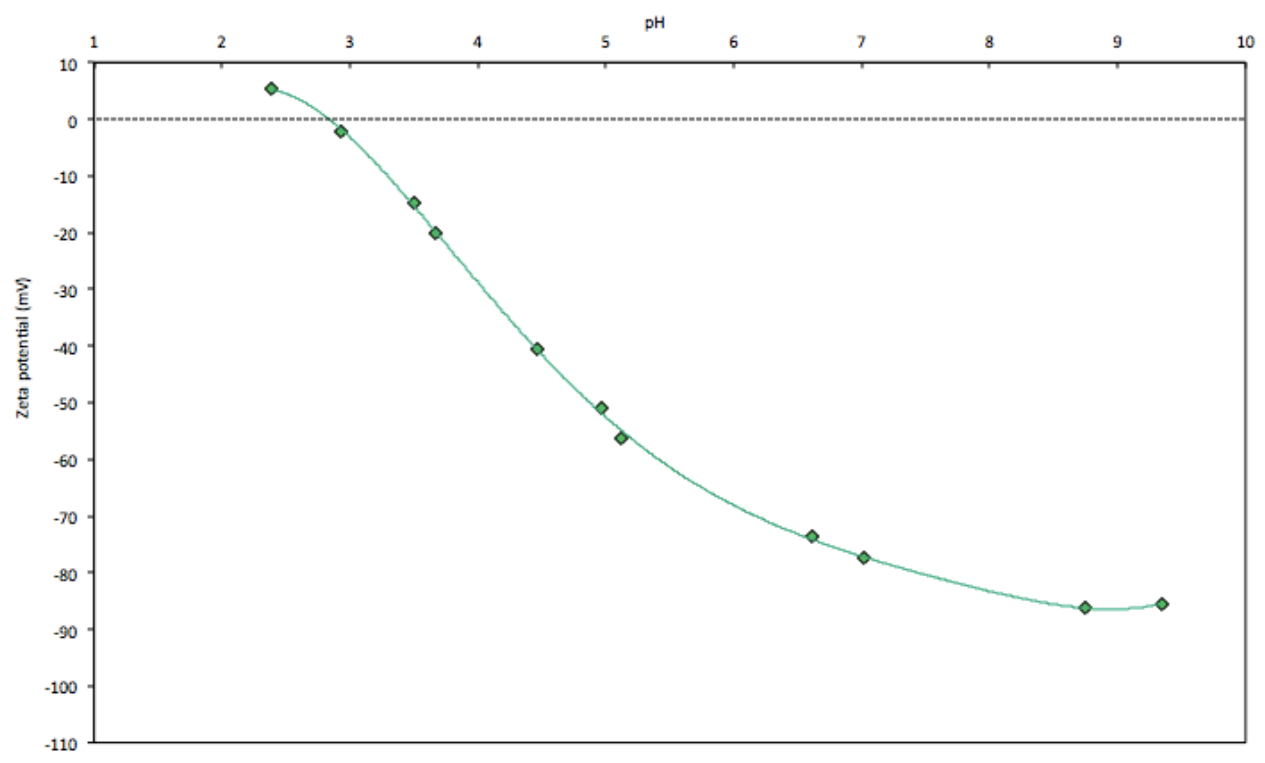

Figure 2. Virgin biomimetic membrane: (a) SEM image of the top surface, and (b) zeta potential measurement. 
(a)

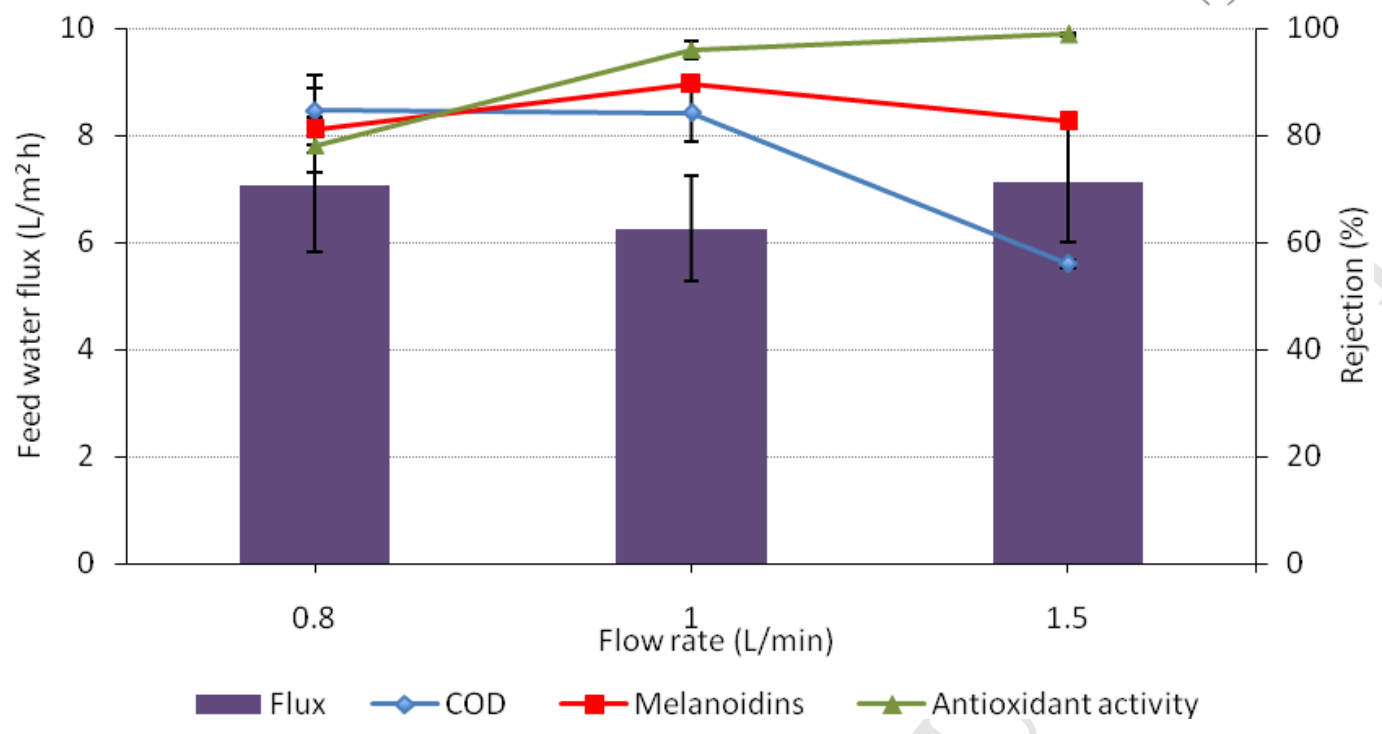

(b)

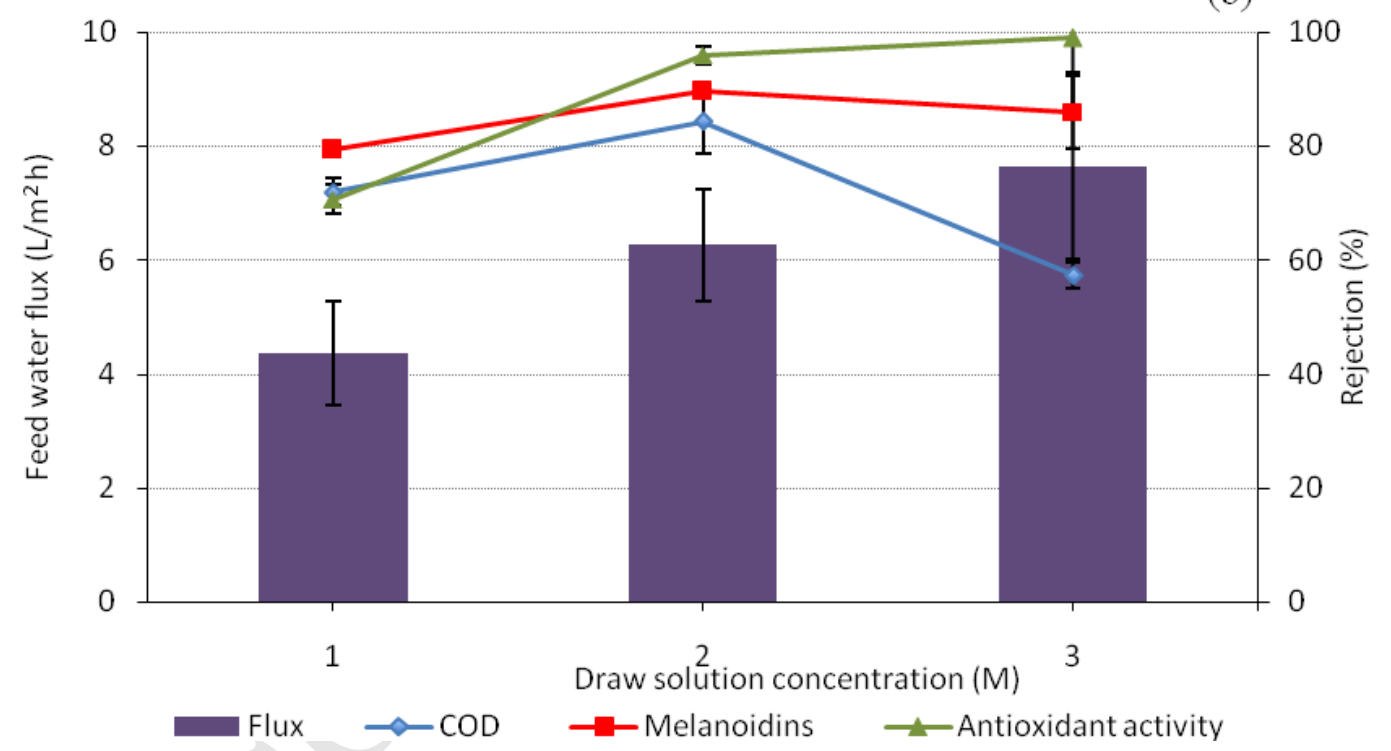

Figure 3. Water flux, rejection of COD, melanoidins and antioxidant activity at (a) varying flow rate (2M draw solution, $3 \mathrm{~h}$ operation time); (b) varying draw solution concentration (1 L/min flow rate, $3 \mathrm{~h}$ operation time). 
(a)
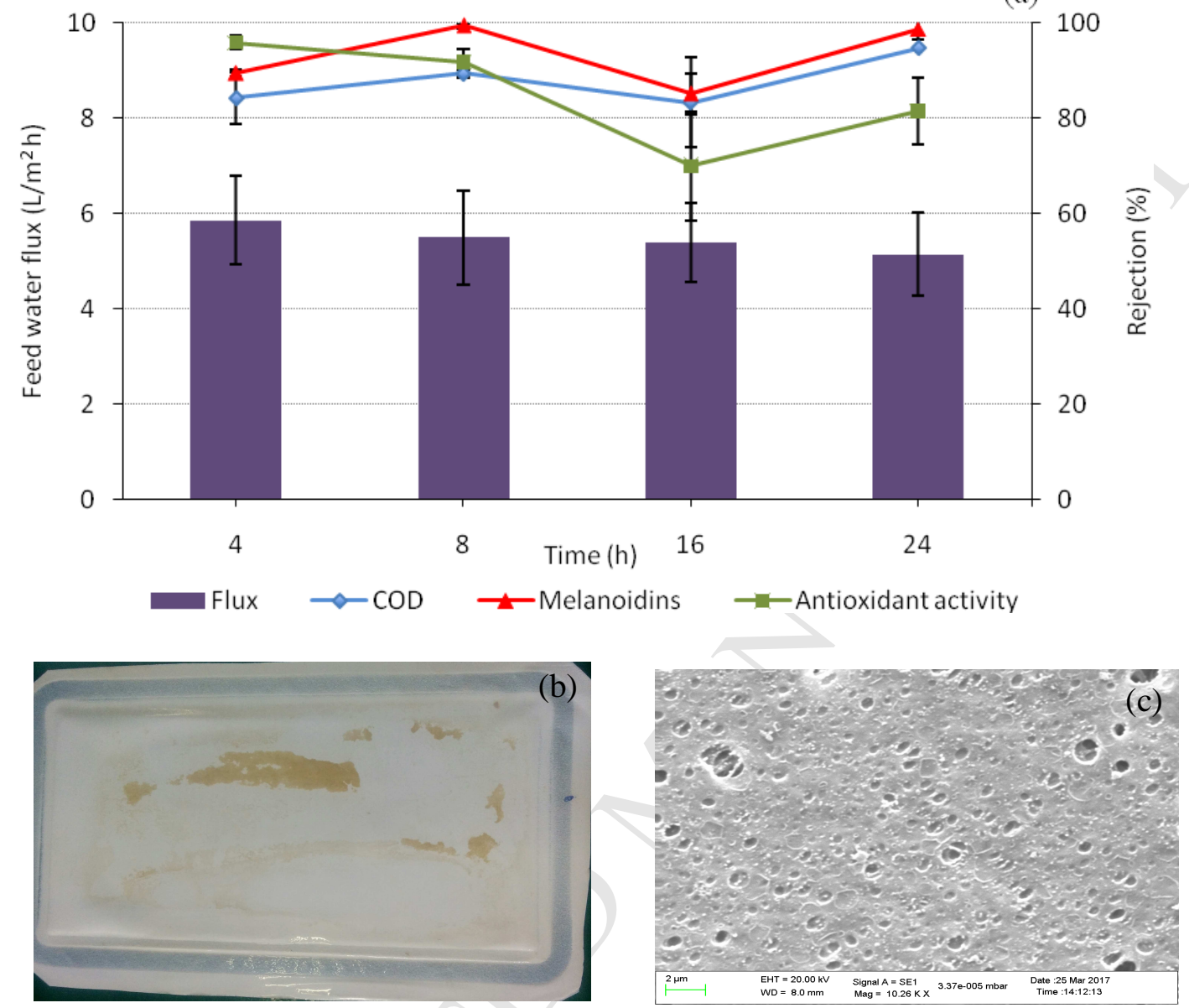

Figure 4. (a)Water flux as a function of time and average rejection of COD, melanoidins and antioxidant activity over $24 \mathrm{~h}$, (b) photo of membrane active side after $24 \mathrm{~h}$ operation, and (c) SEM image of the top surface of used membrane(24h operation). 
(a)

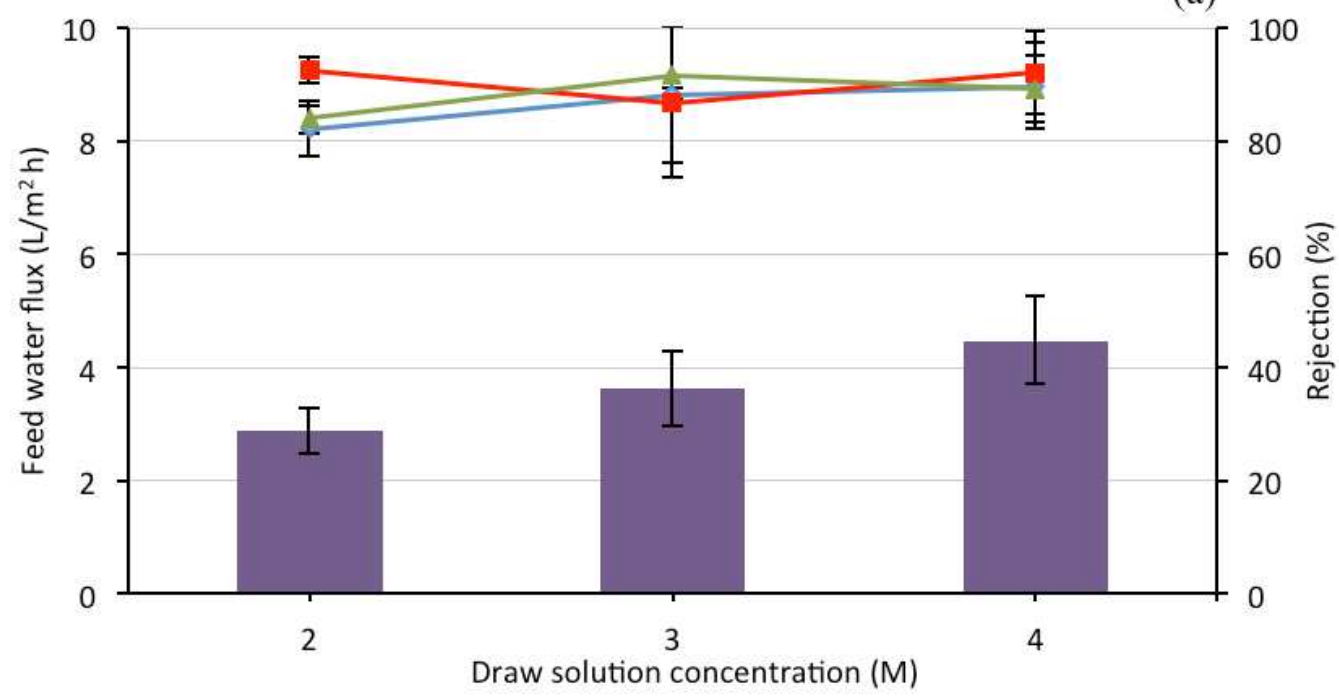

$\rightarrow$ Flux $\leadsto$ COD $\rightarrow$ Melanoidins $\rightarrow$ Antioxidant activity

(b)

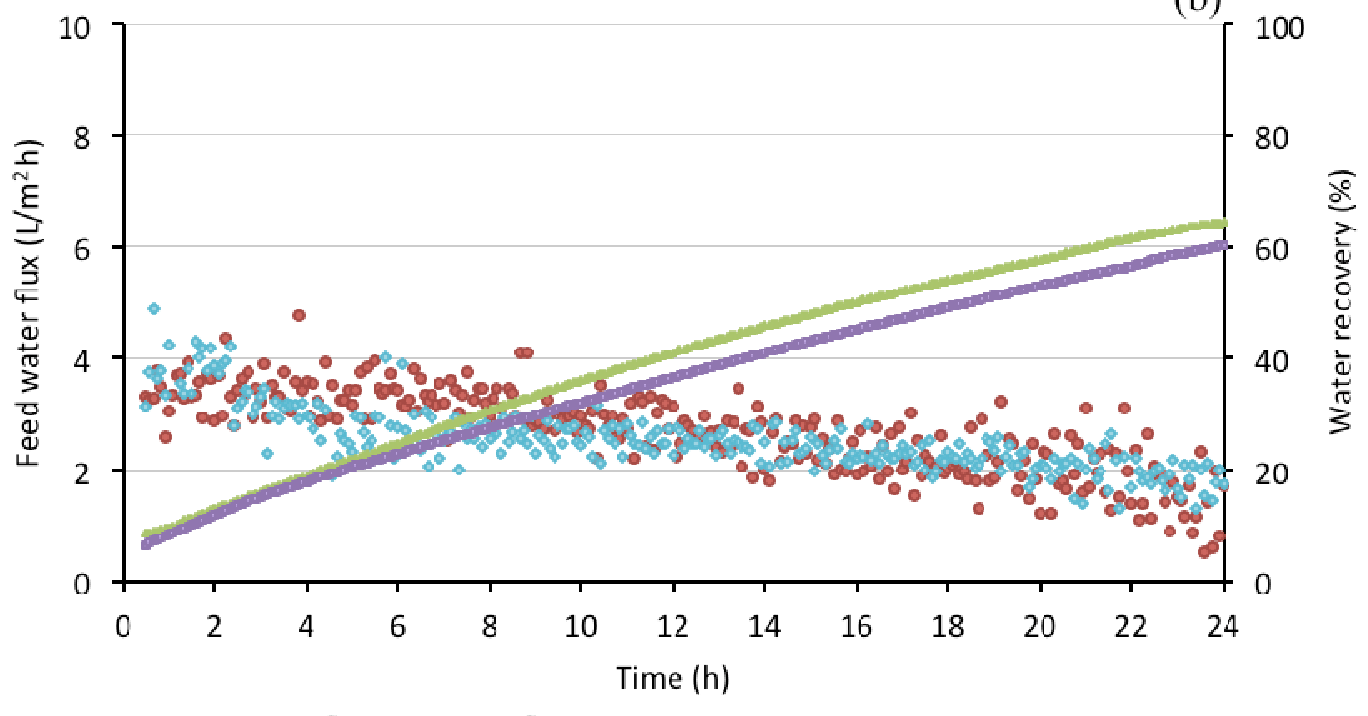

- 3M-flux *4M-flux $\quad 3 \mathrm{M}$-water recovery " $4 \mathrm{M}$-water recovery 


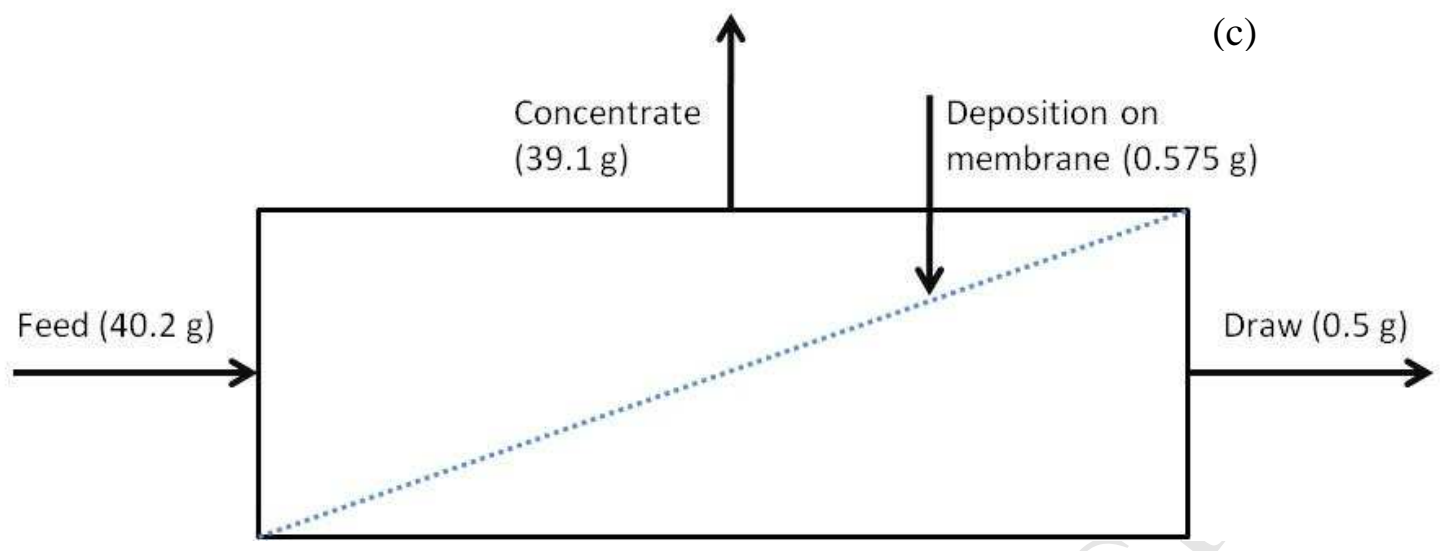

Figure 5. Distillery wastewater dewatering (a) over 4 h by varying draw solution concentration $(2 \mathrm{M}-4 \mathrm{M})$ : water flux and rejection of COD, melanoidins and antioxidant activity (b) over $24 \mathrm{~h}$ at $3 \mathrm{M}$ and $4 \mathrm{M}$ draw solution concentration: water flux and water recovery, and (c) mass balance of melanoidins over $24 \mathrm{~h}$ FO with $3 \mathrm{M}$ draw solution. 


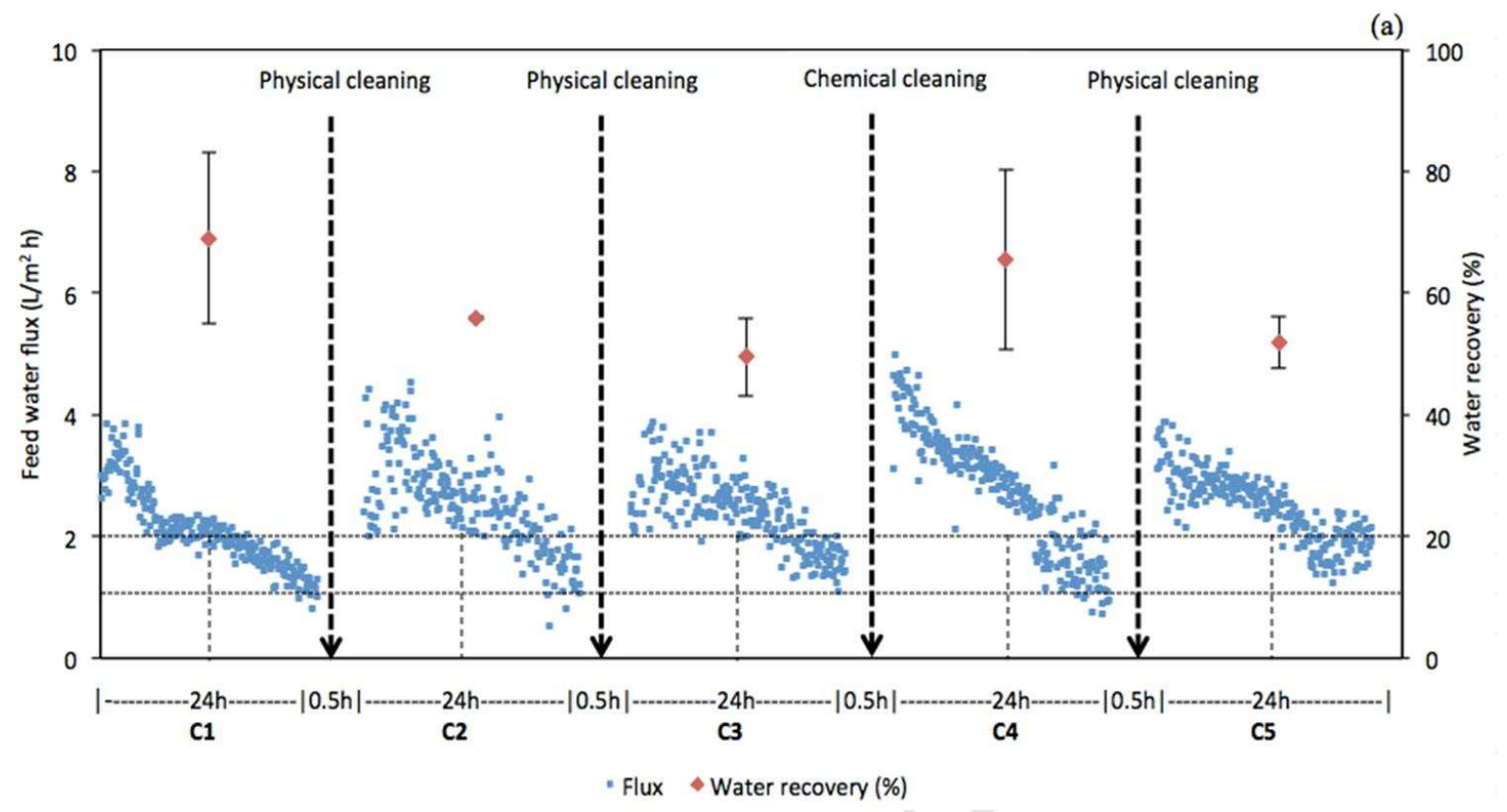

(b)

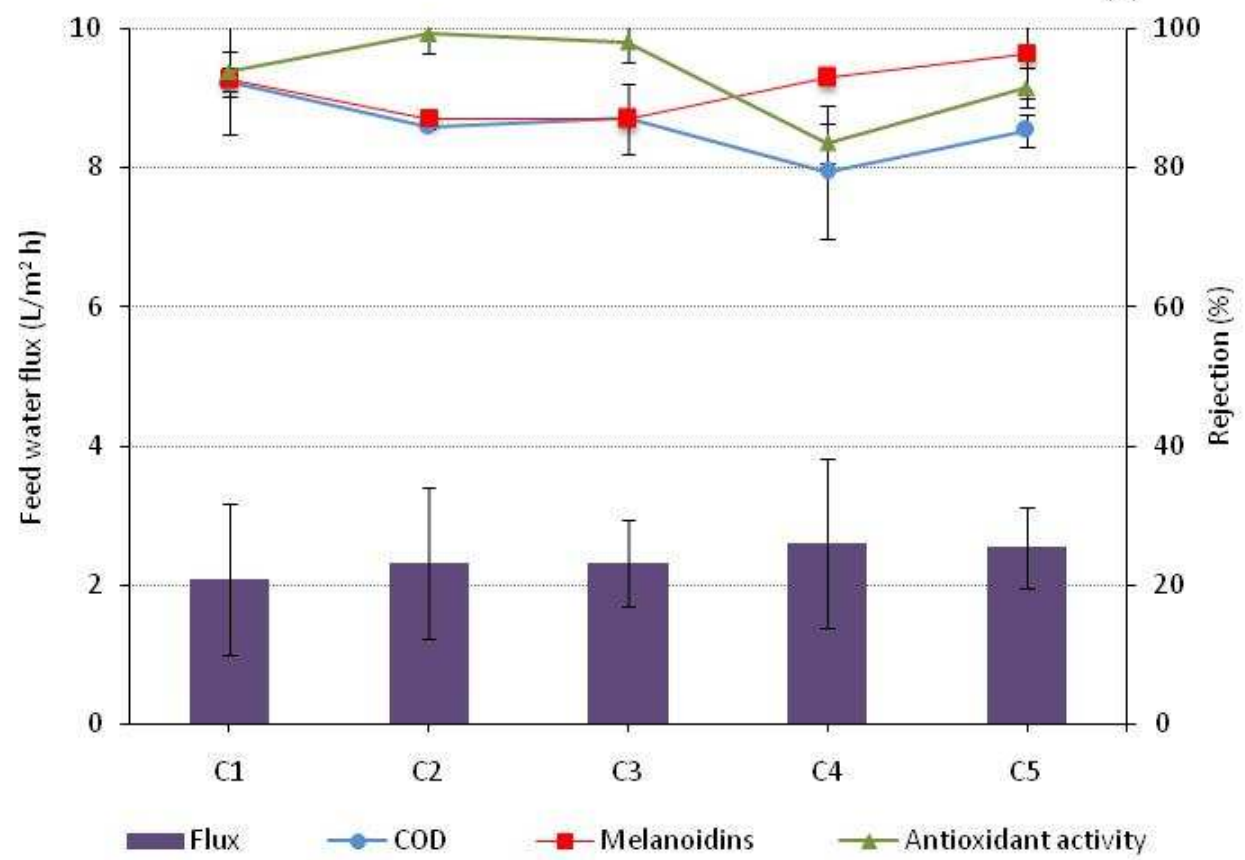

Figure 6. Biomimetic FO membrane performance for distillery wastewater recovery over 5 cycles (C1-C5), each of 24h duration with physical/chemical cleaning (a) water flux and water recovery, and (b) average water flux and corresponding rejection of COD, melanoidins and antioxidant activity. 


\section{Highlights}

- Distillery wastewater and melanoidins solution were concentrated by forward osmosis

- Aquaporin biomimetic membranes and $\mathrm{MgCl}_{2} \cdot 6 \mathrm{H}_{2} \mathrm{O}$ draw solution were used

- Rejection of organics, melanoidins and antioxidant activity was over $85 \%$

- Water recovery of $70 \%$ was obtained with distillery wastewater feed

- Membrane performance was retained with periodic cleaning 